\title{
IS IT RELEVANT TO INTRODUCE THE NEW CONCEPT OF LIMNOSPHERE?
}

\author{
L. TOUCHART ${ }^{1}$, P. BARTOUT ${ }^{2}$
}

\begin{abstract}
Is it relevant to introduce the new concept of limnosphere?
Limnic water is the structuring element of the limnosphere, which could be defined as the envelope of the Earth, where the water cycle transiting through one or more continental water bodies occurs. As a part of epigeosphere and landscape sphere, limnosphere is characterized, practically over its entire thickness and extension, by the contact between atmosphere, lithosphere and hydrosphere. Since 1958 and the coining of the word ecosphere by L.C. Cole, the concepts of sphere and system are close, so that limnosphere may be defined as the envelope of the global limnosystem.
\end{abstract}

Keywords: limnosphere, limnic water, limnosystem

\section{INTRODUCTION}

The hydrosphere was coined in 1875 by the Austrian geologist E. Suess together with the biosphere and the lithosphere. When the Russian oceanographer V.N. Stepanov coined the oceanosphere in 1949 (Степанов, 1983), he disregarded the rest of the hydrosphere, which was later named continental hydrosphere by some authors (Olivry, 1990, Zygmunt et al., 2016). The aim of the paper is to examine the relevance of coining a limnosphere in addition to a possible potamosphere and to increase the glossary of limnology, according to an epistemological approach. In this respect, it is necessary to extract from the definitions of the existing hydrosphere and other geospheres the major criteria which justified their formation and to try to apply them to a prospective limnic envelope of the planet Earth. These determinants can be classified into three families: the component of the sphere, the systemic relationships between the newly created sphere and the other spheres, the concept of sphere as a global envelope.

\section{THE LIMNOSPHERE AS A SET OF LIMNIC WATER}

\subsection{Is the component of the hydrosphere well defined?}

When he invented the word hydrosphere, Eduard Suess (1875) was more concerned by the links, which would be named today systemic, of it with the other spheres than by its characterization as such, so that he did not properly define his

\footnotetext{
${ }^{1}$ Professor, Director of EA 1210 Cedete Laboratory of Geography, University of Orleans, 10 rue de Tours, 45065 Orléans Cedex 2 (France). E-mail: laurent.touchart@,univ-orleans.fr

${ }^{2}$ Senior lecturer, EA 1210 Cedete Laboratory of Geography, University of Orleans, 10 rue de Tours, 45065 Orléans Cedex 2 (France). E-mail: pascal.bartout@univ-orleans.fr
} 
neologism. Great freedom was therefore left to the following authors to define or redefine the hydrosphere according to multiple criteria and with a more or less wide interpretation.

The narrowest definition of the hydrosphere is that of the envelope of surface water in the liquid state (George, 1990, Rat, 1994). A second scientific school admits that the water of the hydrosphere can exist in several phases. For some of these authors, it is the envelope of water in its two liquid and solid states (Roche, 1986), for other the hydrosphere includes the gaseous state (Lageat, 2004). A third way of thinking insists that water also represents, in weight terms, the bulk of living organisms (Любушкина $u$ сотр., 2004).

Finally, the hydrosphere gives rise to multiple definitions by overstepping cryosphere, atmosphere and even biosphere and pedosphere. If we want to create a limnosphere as a part of the hydrosphere, we must go back to the strict characterization of the sphere concept itself.

\subsection{The sphere concept characterized by its components}

Due to the multiplication of spheres created by different authors from the end of the $19^{\text {th }}$ century to the 1930 s, a need to rank the criteria appeared which led to a classification (Исаченко, 1965, Мильков, 1970, Марков, 1980). According to Russian geographers, four criteria may determine the components of a sphere: physical state, chemical composition (Озерский, 2008), level of organization and degree of activity. Limnic water has to be sifted through these four criteria.

\subsection{The characterization of limnic water}

In the following, limnic water includes all inland standing waters lying in lakes, reservoirs, ponds, pools, swamps and other bodies. Unlike water of lentic environment, limnic water is not bio-centered.

According to the criterion of the physical state, limnic water is usually (or should we say centrally) in liquid state, but it can freeze and evaporate. Lake ice is a significant facet of the landscape of mountain, polar and temperate continental lakes, and an important part of the functioning of amictic, cold monomictic and dimictic lakes. Advection fogs form a significant aspect of microclimate above temperate lakes in the spring, and drainage fogs are common in late summer and autumn over water bodies, even smaller ones such as ponds.

According to the criterion of the chemical composition, limnic water is a part of continental waters. As early as 1960, the German geographer F. Wilhelm concluded that continental and marine waters should be distinguished on the criterion of the chemical composition, imposed by an inland catchment area in the first, by the sea in the second case (for example a coastal lagoon). It means that marine lagoons are only affected by quantitative changes in salinity, while lakes add qualitative variability. 
In continental water bodies, not only the concentration of salts that changes, but also the proportion of dissolved elements relative to each other, which depends on the flows in the hydrographical basin. In this context, the limnosphere would be a part of the hydrosphere influenced by the continent, whereas the oceanosphere is the hydrosphere affecting the continent. Without saying so, this was implied by most limnologists working on the ratio of drainage area to lake surface area (Marzolf, 1984, Meybeck et Pourriot, 1991). That is why L. Touchart (1996) compared the very low ratio of Hövsgöl with the Atlantic Ocean and based the geographic identity of this Mongolian lake on this peculiarity. Vanney's conceptual thoughts were going in a close sense when he created "an oceanosphere of influence" to designate our planet (2002b).

According to the criterion of the level of organization, limnic water as such is an inert component. However, it would not be illogical to extend a possible limnosphere to the water taken from water bodies by aquatic organisms or contained in their cells. It should be noted that, although he did not use the concept of sphere, the inventor of limnology himself opposed marine lagoons and inland water bodies on the fact that the plant and animal marine organisms can propagate freely in all waters in direct communication with the sea, whereas their immigration to the lakes can only occur by indirect means (Forel, 1901).

According to the criterion of the degree of activity, limnic water is a mobile component. But the limnosphere could be distinguished from a possible potamosphere precisely because it approaches stability more than this one. On the one hand, limnic water itself is standing water that is to say that its movements, limited, are not due to the slope of the bottom. On the contrary, it is stratified continuously in meromictic lakes, during several years in oligomictic lakes, during one or two seasons in mono- and dimictic lakes, during a few weeks to a few days in discontinuous polymictic water bodies, during a few hours in continuous polymictic water bodies (Lewis, 1983). On the other hand, the standing waters form, as a support, the lentic environment of aquatic biocenosis, where takes place a trophic cycle with main vertical component which is very different from that which occurs from upstream to downstream in the lotic environment (Hynes, 1970).

\section{THE LIMNOSPHERE AS A NETWORK OF LIMNIC INTERACTIONS}

\subsection{The structuring role of limnic water in the water cycle}

In the same way that Vernadsky showed the structuring role of living matter in the biosphere (Вернадский, 1934-1940), some authors have emphasized the structuring role of water in the hydrosphere. Thus, when Ghislain de Marsily (2000) defines the hydrosphere as the surface envelope of the Earth where the water cycle of the planet takes place, combining the atmosphere, the surface part of the continents and the ocean, he revisits the concept according to a vision close to the Vernadsky's thinking. For the purpose of this paper, limnic water is the structuring element of the 
limnosphere, which could be defined as the envelope of the Earth, where the water cycle transiting through one or more continental water bodies occurs.

\subsection{The limnosphere as a part of the epigeosphere}

The Vernadsky's concept of structuring element in a sphere was reworked by Russian geographers to integrate spatio-temporal scales. With that in mind, Andrey Grigoryev coined the geographical envelope in the 1930's (Григорьев, 1966), changed into epigeosphere by Anatoly Isachenko (Исаченко, 1965), and Fyodor Milkov founded the landscape sphere (Мильков, 1970).

In terms of time scales, most authors consider that the geographical envelope of the Earth experienced a first geological stage, then a second biogenic stage, which would correspond to the biosphere in Vernadsky's sense, and then has started a third anthropogenic stage (Любушкина $и$ сотр., 2004). Some authors think that it will move towards a noosphere close to that envisaged by Vernadsky himself. Marina Frolova (2000) showed that Grigoryev's thought emphasized temporal dynamics. In this context, the limnosphere appeared only in the second stage of the development of the planet and it is now evolving under the action of human society, which not only transforms natural lakes, but also creates hundreds of thousands of reservoirs and ponds.

In terms of spatial scales, the first criterion is the thickness of the layer where the interactions take place, according to a meaning close to that of epidermis of the Earth (Tricart, 1962, 1972). If we follow Grigoryev's concept, who thinks that the geographical envelope continues to $800 \mathrm{~m}$ into the lithosphere and on several kilometers to the ozone layer in the stratosphere, the entire limnosphere would be included in this sphere and would participate in all exchanges. If we adopt the Milkov's sphere, most of the oceanosphere escapes him; in this case a deep hypolimnosphere would not belong to the landscape sphere.

The second spatial criterion is the number of external interfaces and the third is composed by vertical and horizontal zonation within the spheric layer. According to the meaning of Isachenko (Исаченко, 1971), shallow marine environments and shores form the most complex place, where the three main abiotic spheres (atmo-, hydro-, litho-) meet. It means for our purposes that the coined limnosphere would be by its very nature in contact with the three spheres practically along its entire thickness and extension. According to the meaning of Milkov (Мильков, 1970), the landscape sphere is precisely the layer 200 to $300 \mathrm{~m}$ thick where the atmosphere, the hydrosphere and the lithosphere interpenetrate each other. Among five types of landscape sphere, continental waters category contains simultaneously rivers, lakes and shallow epicontinental seas. Unlike Milkov, who considers that the thickness of the water column is more decisive than the separation or not with the ocean, we prefer to place the criterion of the opposition between the standing and running waters hierarchically before the thickness of the water column. 


\subsection{Systemic connections between limnosphere and other spheres}

From the beginning, the hydrosphere was coined by E. Suess $(1875, \mathrm{pp}$. 158-159) in a systemic sense; he said that most waters are physically and chemically bound and he emphasized the exchanges with lithosphere and atmosphere. If a limnosphere was coined, it should also interact with the other envelopes. Some examples can be pointed.

Interactions between limnosphere and atmosphere may be apprehended on the scale of the water cycle or be focused on the atmospheric boundary layer which and on the physical epilimnion and the dynamic Ekman layer. Processes such as evaporation and condensation over water bodies, waves and lake currents, concepts like lake limnoclimate (Галазий, Вотинцев, 1975, Ладейщиков, 1982) and pond limnoclimate (Azaroual et al., 2012) are part of the links between the limnosphere and atmosphere. Some geographers have even suggested the creation of a basin of atmospheric influence, in order to map the area which is likely to drop pollutants on the lakes (Чебаненко, 1988).

Interactions between limnosphere and biosphere reflect the mechanisms of lentic ecosystems based on a trophic cycle with a dominant vertical component. (i) The actions of limnosphere on biosphere correspond to those of standing waters regarded as a biotope influencing aquatic biocenosis. (ii) Feedback is less often highlighted in the scientific literature. In terms of quantity, living organisms modify the hydrological balance of water bodies, due to the evapotranspiration of plants. Hydrophyte and helophyte belts may, in some cases, lose more water than open water (DeBusk et al., 1983, Rashed, 2014, Aldomany, 2017). Qualitatively, some filtering organisms are known to purify lake water, such as the endemic copepod Epischura baikalensis in the great Siberian lake (Sars, 1900). (iii) Finally, the reciprocal interactions between limnosphere and biosphere, which Vernadsky would have described as interpenetrating, are affected by changes in geographical scales, which could be used to subdivide the limnosphere if they were used for this purpose. Thus, the fact that the light and the radiative heat are likely to reach the bottom or not, can be considered as a criterion defining and separating lake and pond. This refers to "the [Vernadsky'] envelope penetrated by life and penetrated by the energy of radiation" (Rougerie, 1988, p. 238).

\subsection{Limnosphere as envelope of limnosystem and limnic territory}

For many ecologists and geographers, the concepts of sphere and system are close. When L.C. Cole $(1958$, p. 83) coined the ecosphere, he explained that it was "intended to combine two concepts: the biosphere and the ecosystem". And G. Rougerie (1988, p. 238) noted "how much everything the concept of geosystem covers with space, components and relationships is close to Vernadsky's definition of the biosphere".

If we wanted to follow Cole's idea of ecosphere as envelope of global ecosystem, we would have to focus on biosphere and biocenosis, so that 
limnosphere, as part of geosphere (in the meaning of R.S. Williams, 2012), would be defined as the envelope of the geosystem restricted to limnic biotope. We prefer to follow geographical Isachenko's idea of epigeosphere (Исаченко, 1965) as envelope of global geosystem (in the meaning of В.Б.Сочава, 1963), so that limnosphere would be defined as the envelope of the global limnosystem (in the meaning of L. Touchart and P. Bartout, 2018). It presumes that (i) the role of human societies is not less than this of nature (it is true for sphere concept, Grinevald, 2007, as well as for system concept with the anthroposystem of Lévêque et al., 2000), (ii) biotope is not subservient to biocenosis, (iii) inland water resources depend on lakes and reservoirs much more than on rivers : from $199000 \mathrm{~km}^{3}$ (Cael et al., 2017) to $230000 \mathrm{~km}^{3}$ (Nace, 1969) in natural lakes, $6000 \mathrm{~km}^{3}$ in reservoirs (Shiklomanov, 2000), compared to only $1200 \mathrm{~km}^{3}$ in rivers (L'vovič, 1968).

If a limnic territory is regarded as a part of the earth's surface characterized by significant water bodies of different types (natural lakes, artificial reservoirs, ponds, etc.), which influence the physical environment by their lentic characteristics and are influenced by it, and which are integrated into society and economy and of which inhabitants have appropriated the representation, so that the set of interrelations on several spatial and temporal scales build a geographical identity (Bartout and Touchart, under press), then limnosphere covers all limnic territories. It would mean that limnosphere is evolving toward limnic noosphere. Cultural appropriation of water bodies would no more concern only some territories such as Finland, Switzerland or Brenne, but would become universal.

According to the Russian concept of completeness of a sphere (иелестность сферы), a sphere has a uniqueness in the systemic meaning of the term, because it is not only the sum of its components but adds peculiarities as a system (Любушкина $u$ comp., 2004). It would be the case of limnosphere if we decided to coin it. Indeed, in most of hydrographic basins, chains of reservoirs and ponds propagate limnic conditions throughout the entire hydrographic network without the restoration of river conditions. On a global scale, the removal of all water bodies would change the geosystem of the Earth. Lakes, reservoirs and ponds, because they have much higher organic productivity and sedimentation rates than those in the ocean, play a major role in biogeochemical cycles, especially in the global carbon cycle (Downing, 2009). Assuming that limnosystems and global epigeosphere are indissolubly interrelated, then we can consider that the limnosphere represents the global "limnic footprint" (Bartout and Touchart, submitted). It would help to a more quantitative comprehension integrating extended limnic ratio and density of water bodies.

\section{THE LIMNOSPHERE AS A SPHERIC ENVELOPE OF EARTH}

\subsection{Limnosphere and levels of geographic scales}

According to a limnological geography approach, the world scale forms the highest level in which the other scales fit together (Touchart et al., 2014): the 
zonation of water bodies (specificities of tropical lakes, polar lakes, etc.), the districts of water bodies (for example their grouping in the Germano-Polish lowlands), the role of water bodies in hydrographic basins, the different types of water bodies according to their size (lakes, ponds, pools, swamps), the structure layers and discontinuities within a lake (for example epilimnion and hypolimnion).

The scientific literature about limnology (usually in biology or in geochemistry) shows two methods in change of scales. From local to global scale, most works consist of the study of a water body, most often a natural lake of small or medium size, and then a generalization of the results (in the form of a synthesis until the 1970s, of a mathematical model since that time). From global to local scale, some works use a deductive approach, especially about worldwide distribution of water bodies (Downing, 2010). In fact, each approach, if used alone, can lead to abuse. The former has long led to an overestimation of the functioning of the temperate lake as a global model, dismissing the many nuances of tropical, subtropical (Yoshimura, 1936), polar and subpolar lakes (Bayly and Williams 1973). The latter can lead to risky extrapolations such as senseless inventories of the total area of world's water bodies, as it was denounced by P. Bartout et al. (2015).

The introduction of the limnosphere would make it possible to restore the balance between the two approaches, which would be the counterpart of the balance between the concept of open (stream system, Carter \& Chorley, 1961) and closed (lake as a microcosm, Forbes, 1887) limnosystem (Touchart and Bartout, 2018).

\subsection{Limnosphere, world lake and global lake}

The limnosphere, as another part of the hydrosphere, obviously results from the acceptance of the concept of oceanosphere created by V. Stepanov (Степанов, 1983). The concept of global lake should then be modeled on the already existing world ocean created by Y. Shokalski (Шокальский, 1917), modified by J.-R. Vanney (2002a) in global ocean, which designates an organized whole, considered from a triple point of view: totality, uniqueness and sphericity.

Many spheres do not envelop the Earth in a continuous way (pedosphere, cryosphere, oceanosphere) and it is also the case of the hydrosphere itself, at least in the meaning of the envelope of water in the liquid form. The only way to put the hydrosphere in continuous envelope is to integrate the concept in the water cycle (Margat, 1998). Then the unity of the hydrosphere is determined by the permanent water exchange between its parts and the turnout of water from one state to another and from one place to another.

According to this line of thinking, the limnosphere may also integrate the water cycle. First, the lake is ubiquitous and it is in this sense that we could speak of a world lake. There are water bodies in all climatic zones, at all altitudes and on all continents, including under the Antarctic ice sheet. Then all the water bodies are interconnected and it is in this sense that we could talk about global lake. The discussion lies in the different possible characterizations of this link. Some lakes communicate with each other by lake water through a strait (Michigan and Huron, 
Pskov and Chudsk), others are linked by running water, tributary or emissary. All water bodies are interconnected in the water cycle, producing evaporation, receiving directly precipitations on their surface, affected by infiltration and exfiltration.

The global lake is then a concept close to that of global limnosystem and it is based on the notions of water residence time, opposition between exorheism and endorheism, distance of influence of the water body on the emissary. More generally, limnosphere has a global stabilizing and regulating role. The global water body reduces the flood peaks, maintains the low water levels, restrains the extremes, reduces the thermal range of the emissaries, stabilizes the geomorphologic evolution, suppresses the gravity dynamics due to the slope of the bottom, and causes accumulation rather than ablation. Become aware of it and recognize that artificial reservoirs and ponds belong to the limnosphere would avoid the disruption of river profiles and systems due to dam removing and forced restoration of river connectivity without considering their age and the resetting and rebalancing processes within the hydrosystem.

\subsection{The sphericity of lakes}

Water bodies are spherical segments of the planet and for them this character has direct practical consequences on their functioning, which is not the case on the same level in the potamosphere. The rotundity, the coincidence between the theoretical projection surface and the field surface, the phenomena of optics on the lakes and the importance of the Coriolis force in dynamic limnology form four examples of the spherical character of the limnosphere.

As Aristotle had showed concerning the sea, the founder of limnology noted that an observer on the shores of the Geneva Lake has his horizon bounded by the rotundity of the Earth. A boat that sails a few kilometers ahead of him has its hull hidden behind the line of the horizon (Forel, 1895).

Limnosphere is more regularly spherical than oceanosphere. On a long time scale, limnosphere is not affected by depressions and bulges of the surface of the oceanic sphere, which causes a difference of about $500000 \mathrm{~km}^{2}$ (Любушкина $u$ comp., 2004) between the theoretical projection area of the world ocean (361.3 million $\left.\mathrm{km}^{2}\right)$ and the field area $\left(361.8\right.$ million $\left.\mathrm{km}^{2}\right)$. On a short time scale, inland water bodies, usually calm, present a still water surface, unlike stormy ocean waves.

Lake rotundity has an effect on the reflection of images, which, when it takes place at a very small angle, causes its reversal, but also overwriting. This was observed for the first time on Lake Geneva and mathematically demonstrated by Charles Dufour (1874). The mathematical background was then expanded by $\mathrm{H}$. Griesseier (1953).

The sphericity of water bodies and the rotation of the Earth contribute to the action of the Coriolis force in lakes. For example internal waves are subject to this force (Mortimer, 1955). Currents are also concerned, including plumes of streams in lakes, which are diverted. It gets reflected in the dissymmetrical form of the prodeltas, since the particles settle preferably on the right of the sublacustrine 
deltas in the northern hemisphere (Giovanoli, 1990). Thus the limnosphere imposes to the potamosphere the consequences of its sphericity.

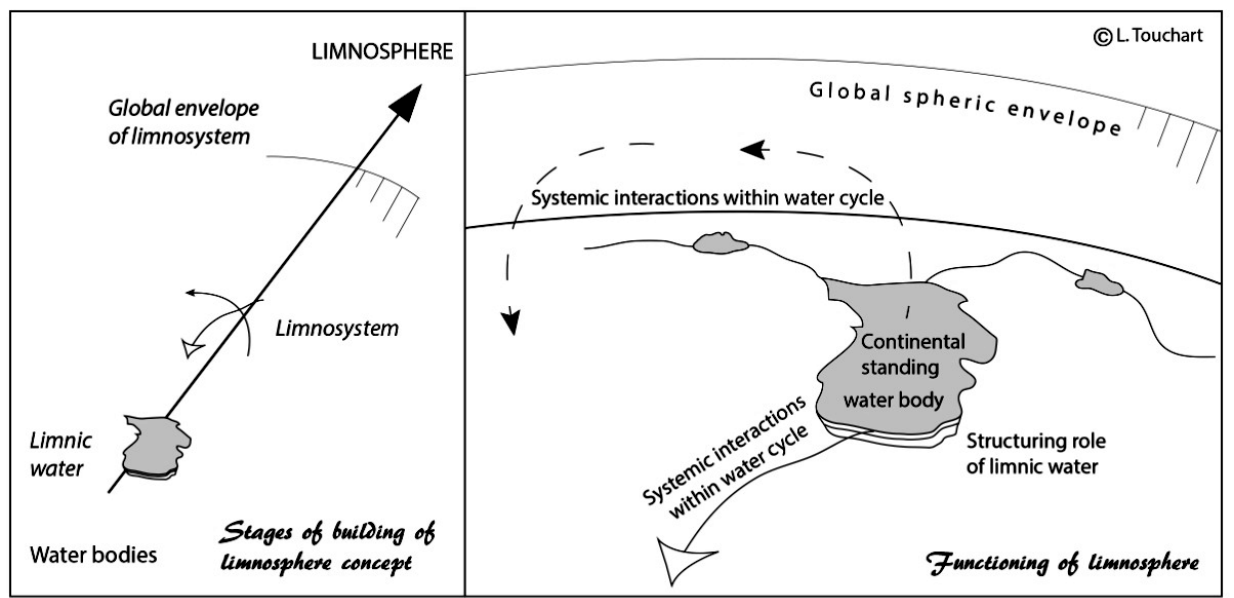

Fig. 1. Limnosphere as spheric envelope of global limnosystem

\section{CONCLUSION}

We suggest defining limnosphere as "global spheric envelope of systemic interactions structured by limnic water within water cycle of the Earth" (fig. 1). A shorter definition may be "spheric envelope of global limnosystem". It involves a comprehensive consideration of societies because (i) limnic water (unlike lentic water) is not a bio-centered concept, (ii) limnosystem is regarded as the set of natural and socio-cultural interactions occurring in a territory centered on a water body, (iii) the concept of sphere (understood in the Vernadsky's sense) includes development and evolution toward noosphere, so that limnosphere takes into account manmade lakes, reservoirs, ponds, pools, artificial water bodies, in context of balanced management, responsible planning and environmental stewardship.

\section{REFERENCES}

1. Aldomany M., 2017, L'évaporation dans le bilan hydrologique des étangs du Centre-ouest de la France (Brenne et Limousin). Université d'Orléans, thèse de doctorat en géographie, $324 \mathrm{p}$.

2. Azaroual A., Bartout P., Touchart L., 2012, "Ponds and climate, the geographical ascendancy relationship" Conference dedicated to the World Meterological Day and the World Water Day, March 23-24, 2012, Universitatea Babeş-Bolyai şi Administraţia Bazinală de Apă Someş-Tisa. Proceedings in Pandi G. and Moldovan F., Ed., Air and water components of the environment. Cluj-Napoca, Presa Universitară Clujeană, 550 p.: 227-235.

3. Bartout P., Touchart L., submitted, "The limnic footprint index" Conference dedicated to the World Meterological Day and the World Water Day, March 1517, 2018, Sovata, Romania. Air and water components of the environment. 
4. Bartout P., Touchart L., under press, "Le territoire limnique, une alternative à la gouvernance des plans d'eau par masses d'eau ?" VertigO - la revue électronique en sciences de l'environnement.

5. Bartout P., Touchart L., Terasmaa J., Choffel Q., Marzecova A., Koff T., Kapanen G., Qsair Z., Maleval V., Millot C., Saudubray J., Aldomany M., 2015, “A new approach to inventorying bodies of water, from local to global scale" Die Erde, 146(4): 245-258.

6. Bayly I.A.E., Williams W.D., 1973, Inland waters and their ecology. Victoria, Longman Australia, 316 p.

7. Cael B.B., Heathcote A.J., Seekell D.A., 2017, "The volume and mean depth of Earth's lakes" Geophysical Research Letters, 44(1): 209-218.

8. Carter C.S., Chorley R.J., 1961, "Early slope development in an expanding stream system", Geological Magazine, 98 (2): 117-130.Cole L. C., 1958, "The Ecosphere" Scientific American, 198 (4): 83-92.

9. DeBusk T.A., Ryther J.H., Williams L.D., 1983, "Evapotranspiration of Eichhornia crassipes (Mart.) solms and Lemna minor L. in central Florida: Relation to canopy structure and season", Aquatic Botany, 16(1): 31-39.

10. Downing J.A., 2009, "Global limnology: up-scaling aquatic services and processes to planet Earth" Verhandlungen der Internationalen Vereinigung für Theoretische und Angewandte Limnologie, 30(8): 1149-1166.

11. Downing J.A., 2010, "Emerging global role of small lakes and ponds: little things mean a lot" Limnetica, 29(1): 9-24.

12. Dufour Ch., 1874, "De l'altération des images par réflexion sur la surface des eaux" Bulletin de la Société Vaudoise des Sciences Naturelles, 13(73) : 303-309.

13. Forbes S.A., 1887, "The lake as a microcosm" Bulletin of the Scientific Association Peoria: 77-87, rééd. 1925, Bulletin of Illinois Natural History Survey, 15: 537-550.

14. Forel F.-A., 1892, 1895, Le Léman, monographie limnologique. Lausanne, F. Rouge, T.1, 543 p., T.2, 651 p.

15. Forel F.-A., 1901, Handbuch der Seenkunde, allgemeine Limnologie. Stuttgart, J. Engelhorn, 249 p.

16. Frolova M., 2000, "Le paysage des géographes russes: l'évolution du regard géographique entre le $\mathrm{xix}^{\mathrm{e}}$ et le $\mathrm{xx}^{\mathrm{e}}$ siècle", Cybergeo : European Journal of Geography [En ligne], Epistémologie, Histoire de la Géographie, Didactique, document 143, mis en ligne le 16 novembre 2000, URL : http://cybergeo.revues.org/1808 ; DOI : 10.4000/cybergeo.1808

17. George P., Dir., 1990, Dictionnaire de la géographie. Paris, PUF, $4{ }^{\text {ème }}$ éd., 512 p.

18. Giovanoli F., 1990, "Horizontal transport and sedimentation by interflows and turbidity currents in Lake Geneva" in Tilzer M.M. \& Serruya C., Ed, Larges lakes: ecological structure and function. Berlin, Springer, 691 p. : 175-195.

19. Griesseier H., 1953, "Zur Reflektion der direkten Sonnenstrahlung an einer bewegten Wasseroberfläche" Acta Hydrophysica, 1 : 107-133.

20. Grinevald J., 2007, La biosphère de l'anthropocène. 293 p.

21. Hynes H.B.N., 1970, The ecology of running waters. Liverpool, University Press, $555 \mathrm{p}$.

22. Lageat Y., 2004, Les milieux physiques continentaux. Paris, Belin, 192 p.

23. Lévêque Ch., Pavé A., Abbadie L., Weill A. \& Vivien F.-D. (2000) "Les zones ateliers, des dispositifs pour la recherche sur l'environnement et les 
anthroposystèmes : une action du programme 'Environnement, vie et sociétés' du CNRS” Natures, Sciences, Sociétés, 8(4) : 43-52.

24. Lewis W.M. Jr., 1983, "A revised classification of lakes based on mixing" Canadian Journal of Fisheries and Aquatic Sciences, 40: 1779-1787.

25. L’vovič M., 1968, "Le bilan hydrique du globe” Annales de Géographie, 77(423) : 553-566.

26. Margat J., 1998, "Hydrosphère" in Dictionnaire français d'hydrologie. Comité National Français des Sciences Hydrologiques, Commission de Terminologie https://hydrologie.org/glu/FRDIC/DICHYSPH.HTM

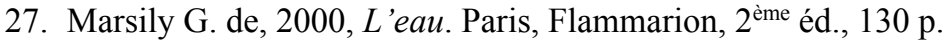

28. Marzolf G.R., 1984, "Reservoirs in the Great Plains of North America" in Taub F.B., Ed, Lakes and Reservoirs. Amsterdam, Elsevier, col. «Ecosystems of the World » $n^{\circ} 23,643$ p.: 291-302.

29. Meybeck M. \& Pourriot R., 1991, "Introduction: les lacs comme modèle d'océan" Océanis, 17(5) : 511-515.

30. Mortimer C.H., 1955, "Some effects of the earth's rotation on water movement in stratified lakes" Verhandlungen der Internationale Vereinigung für theoretische and angewandte Limnolologie, 12: 66-77.

31. Nace R.L., 1969, "World water inventory and control" in Chorley R.J., Water, earth and man: a synthesis of hydrology, geomorphology and socio-economic geography. London, Methuen, 588 p.: 31-42.

32. Olivry J.-C., 1990, Géodynamique de l'hydrosphère continentale. Montpellier, ORSTOM, rapport d'activité de l'UR 2A (1987-1990), 147 p.

33. Rashed A.A., 2014, "Assessment of aquatic plants evapotranspiration for secondary agriculture drains (case study: Edfina drain, Egypt)". The Egyptian Journal of Aquatic Research, 40(2): 117-124.

34. Rat P., 1994, "L'eau des géologues et la machine Terre » in Perrot M., Dir., L'eau, mythes et réalités. Dijon, Editions universitaires, actes du colloque organisé à Dijon du 18 au 21 novembre 1992, 347 p.: 159-174.

35. Roche M.F., 1986, Dictionnaire français d'hydrologie de surface. Paris, Masson, $288 \mathrm{p}$.

36. Rougerie G., 1988, Géographie de la biosphère. Paris, Armand Colin, 288 p.

37. Sars G. O., 1900, "On Epischura baikalensis, a new Calanoid from Baikal Lake" in Salensky W. et Schmidt R., Réd., Annuaire du Musée Zoologique de l'Académie Impériale des Sciences de St.-Pétersbourg. St.-Pétersbourg, édition de l'Académie Impériale des Sciences, vol. V : 226-240.

38. Shiklomanov I.A., 2000, "Appraisal and assessment of world water resources" Water International, 25(1): 11-32.

39. Suess E., 1875, Die Entstehung der Alpen. Wien, Wilhelm Braumüller, 168 p.

40. Touchart L. (1996) Le Koussougol, un Atlantique lacustre" Norois, 43(170) : 323337.

41. Touchart L., Bartout P., 2018, "Le limnosystème est-il un concept géographique?" Annales de Géographie, 127(719) : 29-58.

42. Touchart L., Bartout P., Nedjai R., 2014, "La géographie limnologique en France : conjugaison de l'espace et du temps pour la compréhension des relations hommemilieu" Bulletin de la Société géographique de Liège, 62 : 93-103.

43. Tricart J., 1962, L'épiderme de la Terre, esquisse d'une géomorphologie appliquée. Paris, Masson, $168 \mathrm{p}$.

44. Tricart J., 1972, La Terre planète vivante, Paris, PUF, 184 p. 
45. Vanney J.-R., 2002a, Géographie de l'océan global. Paris, GB, 335 p.

46. Vanney J.-R., 2002b, "La Mer domine la Terre, entretien avec L. Lucchini" in Annuaire du droit de la mer 2001. Paris, A. Pedone, tome VI : 645-668.

47. Wilhelm F., 1960, "Seen als geographisches Forschungobjekt" Berichte zur deutschen Landeskunde, 25(2): 305-321.

48. Williams R.S. Jr., 2012, "Introduction - changes in the Earth's cryosphere and global environmental changes" in Williams R.S. Jr. and Ferrigno, J.G., eds., State of the Earth's cryosphere at the beginning of the 21st century-Glaciers, global snow cover, floating ice, and permafrost and periglacial environments. Denver, U.S. Geological Survey Professional Paper 1386-A, 546 p.: A1-A68.

49. Yoshimura S., 1936, "A contribution to the knowledge of deep water temperatures of Japanese lakes" Japanese Journal of Astronomy and Geophysics, "Part I. Summer temperatures" 13: 61-120, "Part II. Winter temperatures" 14: 57-83.

50. Zygmunt M., Rajner M., Liwosz T., 2016, "Assessment of continental hydrosphere loading using GNSS measurements" Reports on Geodesy and Geoinformatics, 101: 36-53.

51. Вернадский В.И., 1934-1940, Проблемы биогеохимии. Москва, Наука, переиздание 1980, 320 с.

52. Галазий Г. И., Вотинцев К.К., Ред., 1975, Круговорот вещества и энергии в озерных водоемах. Новосибирск, Наука, 474 с.

53. Григорьев А.А., 1966, Закономерности строения и развития географической среды. Избранные теоретические работы. Москва, Мысль, 382 с.

54. Исаченко А.Г., 1965, Основы ландмафтоведения и физико-географическое районирование. Москва, Высшая школа, 327 с.

55. Исаченко А.Г., 1971, «Системы и ритмы зональности » Известия Всесоюзного Географического общества, 103(1) : 10-26.

56. Ладейщиков Н.П., 1982, Особенности климата крупных озёр на примере Байкала. Новосибирск, Наука, 318 с.

57. Любушкина С.Г., Пашканг К.В., Чернов А.В., 2004, Общее землеведение. Москва, Просвещение, 288 с.

58. Марков К. К., отв. ред., 1980, Физическая география Мирового океана, Ленинград, Наука, 362 с.

59. Мильков Ф.Н., 1970, Ландшафтная сфера Земли. Москва, Мысль, 1970, 208 c.

60. Озерский А.Ю., 2008, Основы геохимии окружающей среды. Красноярск, ИПК СФУ, $316 \mathrm{c.}$

61. Сочава В.Б., 1963, «ОПределение некоторых понятий и терминов физической географии » Доклады Института Географии Сибири и Дальнего Востока, 3 : 50-59.

62. Степанов В.Н., 1983, Океаносфера. Москва, Мысль, 270 с.

63. Чебаненко В.В., 1988, «Влияние дальнего и ближнего переноса промышленых выбросов на загрязнение оз. Байкал » География и природные ресурсы, $4: 79-83$.

64. Шокальский Ю.М., 1917, Океанография. Петроград, А.Ф. Маркс, 616 с. 